\title{
The effect of plant density to the yield results and the yield components of maize hybrids
}

\author{
Péter Könczöl \\ Monsanto Hungaria Ltd. Research Station, Budapest, Hungary \\ peter.konczol@monsanto.com
}

\begin{abstract}
SUMMARY
Maize is the crop that is produced on the second largest area in our country, in Hungary. It is planted on nearly $25 \%$ of the country's growing area and it was produced on 1090439 hectares in 2016. Despite the continuous development of the biological basis and production technology, the growth of the yield results is not constant, its fluctuation is significant. It can be even up to $60 \%$, because of the extremity of the years. The exploitation of the yield potential of modern hybrids is possible if we harmonize the effects of the ecological factors and properly applied instruments of agro technology and by these we ensure their interaction to reach a favorable outcome. The applied plant density is an important, well researched, but at industrial level a not enough utilized element of the maize production.

The results of the extensive tests, done between 2009 and 2015, showed that the genotype, the year effect and the plant density are in strong correlation with each other determining the yield results. In the past seven years the examined genotypes reached the highest yield performance at the highest plant densities. The early hybrids (RM90-95, FAO200-300) are capable of producing them at higher plant density, while in case of the mid and late maturity varieties the further increasing of the density after reaching the optimum level led to yield depression. According to our experimental results, the yield is in close positive correlation with the increase of the plant density. The effect of the growing season has great significance in forming the yield results and this determines the applicable plant density too.

The yield of maize is determined by a resultant of components. The main component is the number of ears per plant and the amount of kernels per ear, which is calculated from the number of kernels on an ear and the weight of them. The number of the kernels on an ear is calculated from the number of rows on the cob multiplied by the number of seeds in one row on the cob. In dry years, at lower yield levels the yield decreases because of the shorter ears, while at the higher levels the number of kernels in a row and the thousand-kernel weight decreases, causing yield depression this way. From our examinations it turned out that the plant density reaction of a genotype is individual, every variety reaches its maximum kernel number per hectare - in other words the maximum yield - in an individual way.
\end{abstract}

Keywords: maize, plant population, density, yield components, yield level, drought, density-stress

\section{ÖSSZEFOGLALÁS}

A kukorica hazánkban a második legnagyobb felületen termesztett növény, a vetésterület közel 25\%-án vetik, 2016 -ban 1090439 hektáron termesztették. A biológiai alapok és a termesztéstechnológia folyamatos fejlesztése ellenére a terméseredmények növekedése nem állandó, az évjáratok szélsőségei miatt ingadozása igen jelentős, akár $60 \%$ is lehet. A modern hibridek terméspotenciáljának kihasználása úgy lehetséges, hogy az ökológiai faktorok hatásait az agrotechnika megfelelö módon alkalmazott eszközeivel harmonizáljuk és így biztositjuk a kedvezö kimenetelü kölcsönhatásukat. Az alkalmazott töszám a kukoricatermesztés egy fontos, sokat kutatott, de üzemi szinten nem megfelelöen kihasznált eleme.

A 2009 és 2015 között végzett széleskörü tesztelések eredményei azt mutatták, hogy a genotípus, az évjárat és a töszám egymással szoros kapcsolatban határozzák meg a terméseredményeket. Az elmúlt hét évben vizsgált hibridek a legmagasabb termést a magasabb töszámokon érték el. A korai fajták (FAO200-300) alkalmasak a magasabb töszámon történö termesztésre, míg a közép-és késői érésü fajták esetében az optimum elérése után a további sürités termésdepresszióhoz vezet. A töszám növelésével a termés szoros pozitiv összefüggésben áll a kísérleti eredményeink szerint. Az évjárathatásnak nagy jelentösége van a terméseredmények kialakitásában, ez az alkalmazandó töszámot is meghatározza.

A kukorica termését komponensek eredöje határozza meg. Fökomponens a növényenkénti csőszám és a csövenkénti termés mennyisége, ami a csövenkénti szemek száma és azok tömege. A csövenkénti szemek száma a sorok számából és a soronkénti szemek számából adódik össze. Szárazabb években, alacsonyabb termésszinteken a termés csökken a rövidebb csövek miatt, míg a soronkénti szemszám, valamint az ezerszemtömeg csökken a magasabb töszámokon, így okozva termésdepressziót. Vizsgálataimból megállapitható, hogy a fajták töszámreakciója egyedi, minden típus egyedi módon éri el a hektáronként maximális szemszámot, azaz a maximális termést.

Kulcsszavak: kukorica, tőszám, állománysürüség, terméskomponensek, termésszint, szárazság, tőszám-stressz

\section{INTRODUCTION}

The genetic potential of maize is constantly growing. In contrast, the Hungarian average yield is not following it. The environmental effects and the given year effect - notably the available amount of water - significantly influence the yield results. With the elements of the production technology, farmers can reduce the negative effects of the disadvantageous growing seasons. The great question is how the variety users can take more and more advantage of the potential of the modern hybrids. The effect of plant density to the yield is obvious and several former researches also discuss and confirm it (Widdicombe and Thelen 2002, Molnár and Sárvári 2005, Sárvári and Boros 2009, Murányi and Pepó 2014). In Hungary the instability of years is significant, drought is one of the most important limiting factors in the success of the production, that predicts the opportunity of the spreading of the use of hybrids in the future that are independent from plant density 
and belong to the early maturity group (Maddonni and Otegui 2004, Berzsenyi and Tokatlidis 2012). The reaction of the genotypes to the increase of density and their characteristics in connection with changing the plant density are also different (Edwards 2016), that needs to be considered when connecting into cultivation and the influence of the ecological factors also need to be interpreted, because the behavior of the hybrids are different at different yield levels and maize is especially sensitive to water supply (Pepó and Murányi 2015) and does not tolerate extreme characteristics of the growing area (Ruzsányi and Csajbók 2001). Several researches point out that in case of hybrids belonging to the early maturity group the ratio between the increase of their yield and the increase of the plant density is linear (Sárvári and Boros 2010). They show higher plasticity in their plant density optimum (Sarlangue et al. 2007). It is likely to cause that the average maturity of widespread hybrids slid from the group of 400 to the group of 300 . Today in Hungary $73 \%$ of the twenty most popularly grown hybrids belong to FAO300 maturity group and this tendency indicates well the practice in production. The growing circumstances in Hungary are hectic, our arid climate is always changing and it becomes dryer and warmer in the period to what the maize is sensitive to. This is the reason why it is important to handle the results of the plant density experiments with care, because hybrids react to the change of the plant density specifically (Murányi and Pepó 2015). Some of them have wide optimum and there are some that don't (Sárvári et al. 2007). The final yield of maize is developing during a long process, each yield component is determined in different phenological stages, first the cob, then the number of kernels per cob is formed (Sangoi 2001). The importance and the sensitivity of the yield components was the topic of several researches and because of the above mentioned ecological variability it is essential for us too to examine these factors. The yield level of maize is constantly growing that can be explained with the growing number of kernels per plant and the increasing weight of the kernels (Echarte et al. 2006). The literature also says that the reaction of the new hybrids to the lack of resources grew, that means the sensitivity to changes of the environment is higher. The negative reaction of the weight of the kernels while increasing the plant density is confirmed by several researches (Lie et al. 2015). Beyond these, the increasing number of the barren plants and the decrease of the strength of the stalk and roots are also important result of the unprovoked increase of plant density (Maddonni and Otegui 2004, Sárvári and Boros 2008). Some authors write clearly that maize is one of the most sensitive grass species in an intra-specific competition (Maddonni and Otegui 2006). The individual production decreases constantly and in every case when increasing the plant density (Edmeades and Daynard 1979, Nagy 2007). However, the yield per growing area unit grows to a limit that is specific to the variety and to the given ecological circumstances and beyond that it decreases because of the further plant density stress. Tollenaar (1989) found that increased plant densities increased total dry matter, but decreased the harvest index. The objective of this work was to analyze responses of widely used commercial hybrids to different plant densities under various growing conditions. The relationship between yield and plant densities' effects on yield components and farmer's profit were analyzed during 7 years.

\section{MATERIAL AND METHODS}

During the field experiment between 2009 and 2015 we have performed our small plot experiments at 7 testing locations in random block layout, with 3 repetitions and with 5 different plant densities $\left(50000 \mathrm{ha}^{-1}\right.$ $\left.60000 \mathrm{ha}^{-1}-70000 \mathrm{ha}^{-1}-80000 \mathrm{ha}^{-1}-90000 \mathrm{ha}^{-1}\right)$. The hybrids brought into the experiment were widely applied, well known genotypes in the Hungarian public production. We have examined the genotypes separated into two maturity groups (RM90-95, FAO200-300 and RM100-105, FAO400-500).

As part of the experiment we have examined the interactions between the varieties and the plant density and interactions between the genotypes, the plant density and growing season, furthermore the effect of the plant density to the agronomical characteristics. In two experiment years we have examined the yield components as well. After the merged analysis and evaluation of the results we have divided them into simulated yield levels $\left(0-7 \mathrm{tha}^{-1}, 7-11 \mathrm{tha}^{-1}, 11<\mathrm{tha}^{-1}\right)$ we have also done cluster analysis. The aim of the examination of the environmental effects on yield components was to fully understand the individual, hybrid specific reactions, that is also essential from the perspective of the development of the sustainable maize production.

\section{RESULTS AND DISCUSSION}

The plant density experiments provided an opportunity for us to observe the genotypes' reactions given to the effects of the environment in details and to understand the individual characteristics of the varieties. In our experiments, besides examining the plant density reaction showed at different yield levels, we have observed and evaluated the change in the following yield components at different plant densities:

- ear length $(\mathrm{cm})$,

- ear circumference $(\mathrm{cm})$,

- ear diameter $(\mathrm{cm})$,

- cob diameter without kernels $(\mathrm{cm})$,

- kernel length $(\mathrm{cm})$,

- number of kernel rows (pcs),

- number of kernels in a row (pcs),

- thousand-kernel weight [TKW] (gram).

An important moment of the research was to understand that the reactions of the hybrids are individual, even if we could find general conclusions based on the data. The final yield can be calculated from the number of kernels on an area unit multiplied by their weight. Every hybrid reaches its final yield by using individual strategy, with a different combination of its yield forming characteristics. The increase of the plant density had a negative effect on every yield component/forming characteristics. The individual production of the hybrids decreased because of the increasing stress caused by the smaller and smaller living space. At the same time this decrease is not directly proportional with the increased number of the added plants, kernels on the area unit that come 
from the higher plant density. This slide results in the yield increase. The modern hybrids of present days have better technology tolerance, they can cope with the stress of the increased density easier with their better agronomical characteristics, phenotype. This tendency is confirmed by the related literature.

The correlations between the plant density and yield

If we consider all of the data points, we can see that out of our hybrids, the highest yield/kernel number was reached with the highest plant density (Figure 1). The plant density and yield show strong, positive correlation. Our results show that early hybrids (RM90-95, FAO200 and FAO300) are especially capable to be produced at a higher plant density. They have reached their maximum yield with the highest plant density. In case of the midterm and late hybrids (RM100-105, FAO400 and FAO500) the correlation is not that strong $(\mathrm{r}=0.601)$. In their case we could measure the maximum yield at $70000 \mathrm{ha}^{-1}$. These hybrids reacted with depression for further increase of density. We can also determine that in spite of the higher sensitivity to plant density increase, showed by the late group, their year stability was higher, against the early group and it can clearly be seen that here the yield potential is also much higher, especially in favorable growing conditions.

Figure 1: The effect of plant density on yield (2009-2015)

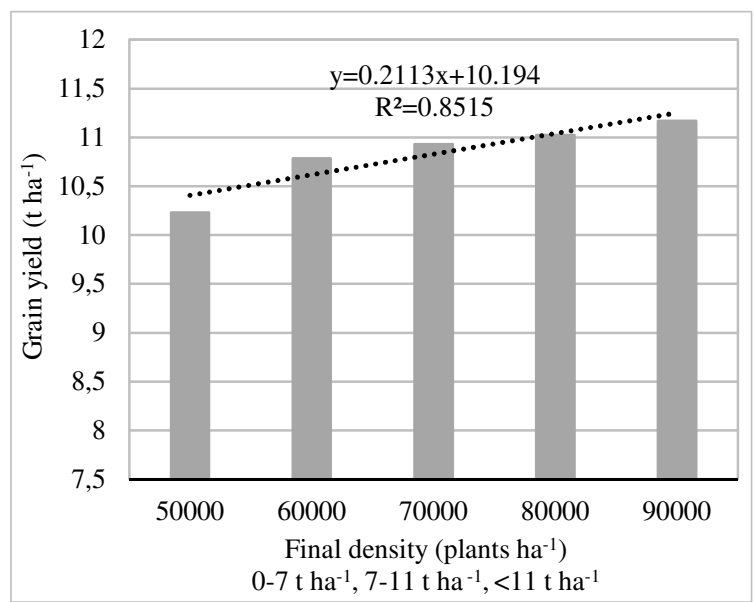

The correlations between the plant density and yield at different yield levels

At low yield level $\left(0-7\right.$ t ha $\left.^{-1}\right)$ the 50-60 000 plants $\mathrm{ha}^{-1}$ seems to be the appropriate density for an established stock and the yield loss is significant in both groups due to the effect of further increase of plant density. The loss here is definitely because of the stress caused by the heat and drought stress. Under these conditions, all elements of the yield components characteristics were deteriorated, shorter and thicker ears grow, on these cobs there will be less kernels per rows and the number of barren plants also increases significantly.

At medium yield level in both maturity groups the 60-80 000 plants $\mathrm{ha}^{-1}$ seem to be appropriate. In the FAO400-500 group we could clearly detect yield depression at 80-90 000 plants ha ${ }^{-1}$ plant density. Considering that the long-term average yield for maize in Hungary is around 7-7.5 $\mathrm{t} \mathrm{ha}^{-1}$, these results are important starting point in our work. In the early yield group, the growth of the yield is constant until 80-90000 plants ha ${ }^{-1}$ plant density as an effect of the increase of the number of plants in the given area unit. In the late group the curve is flatter, but at 90000 plants $\mathrm{ha}^{-1}$ we can see increasing yield too. These tendencies make us say that those farmers who have good and dependable circumstances for production and are willing to invest in higher yield results could make a large profit by choosing the appropriate variety for growing (Figure 2).

\section{The effect of plant density on agronomical characteristics}

During the examination of the stalk and root characteristics of the hybrids we could determine that there is no, or very weak positive correlation with the applied plant density (root lodging $\mathrm{r}=0.19$, stalk lodging $\mathrm{r}=0.11$ ). During our experiments set under Hungarian circumstances, I could not detect the effect of plant density on ear height $(\mathrm{r}=0.07)$ and plant height $(\mathrm{r}=-0.04)$. Neither the silking $(\mathrm{r}=0.03)$, nor the anthesis $(\mathrm{r}=0.01)$ is in connection with the increase of plant density. At high plant density the number of kernels per plant decreases because of the sliding of the anthesis silking interval (ASI). This is more significant especially in dryer years.

Figure 2: The effect of plant density at different yield levels

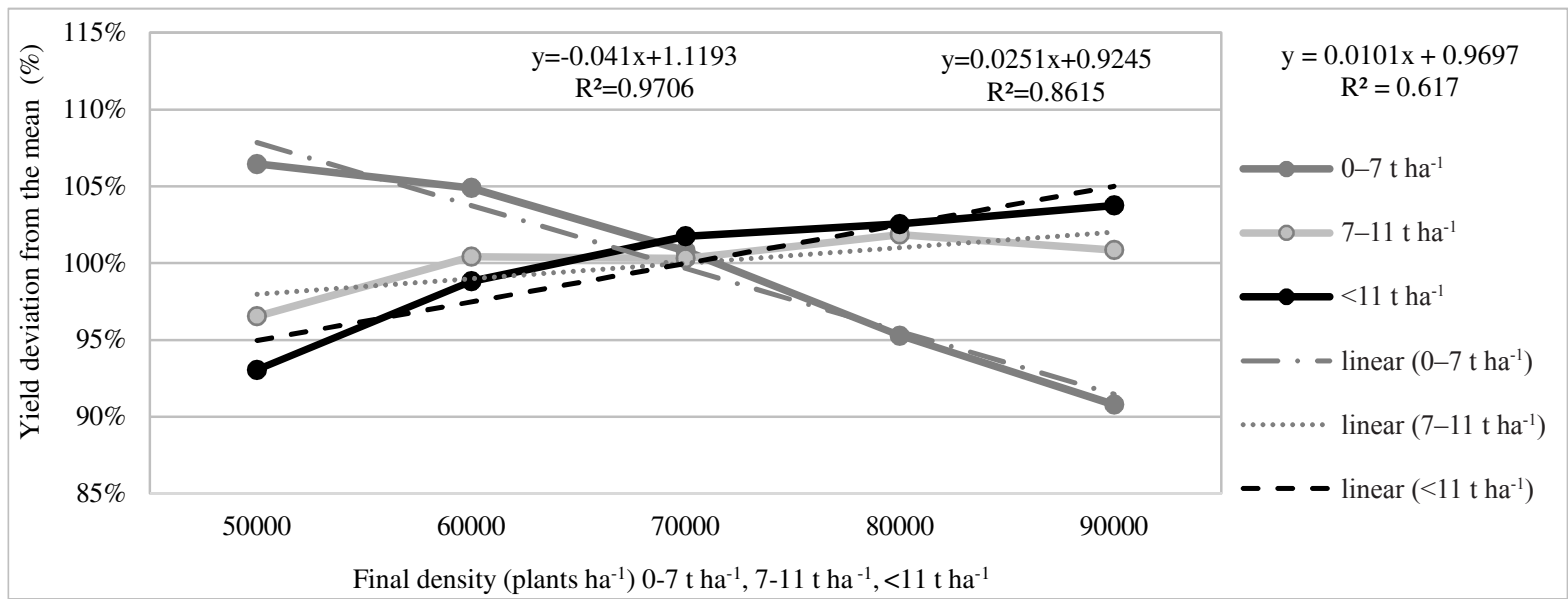


The difference between the plant density depending and plant density independent genotypes

The reactions of the varieties to plant densities are also significantly influenced by the ear characteristics of the given genetic combination. The hybrids with a flexible type ear can brilliantly compensate the lower plant density, because in this case they develop longer ears - lower stress level, because the competition for living space is lighter - than at higher plant density. These genotypes show significant differences between the lengths of their ears, the increasing of their density is not reasonable. They can be reliable hybrids of mostly extensive, low cost areas. In case of hybrids like these, there is no correlation between the plant density and yield (Figure 3). In contrast, the maize with determined (fixed) ears are relatively stable in length, in their case we can reach better production results with increasing the plant density (Figure 4), on the basis of the more ears, the more yield precept. In case of these hybrids, the enhancing of the plant density obviously brings the increase of the yield. The correlation between these characteristics can be confirmed statistically and it is tight. The two types need different application, understanding this can be critical in those production situations when a decision does not seem to be relevant, but still it can bring an essential change in the economic results.

Figure 3: Correlation between plant density and yield in case of flexible type of ear

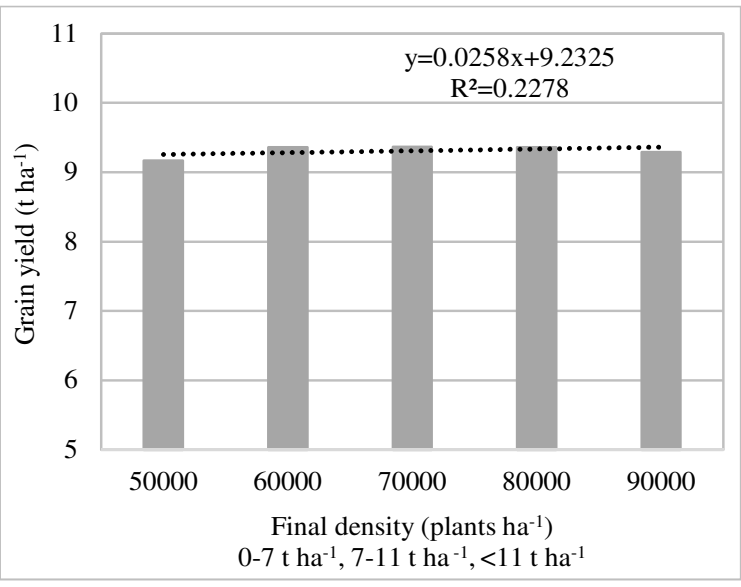

Figure 4: Correlation between plant density and yield in case of determined type of ear

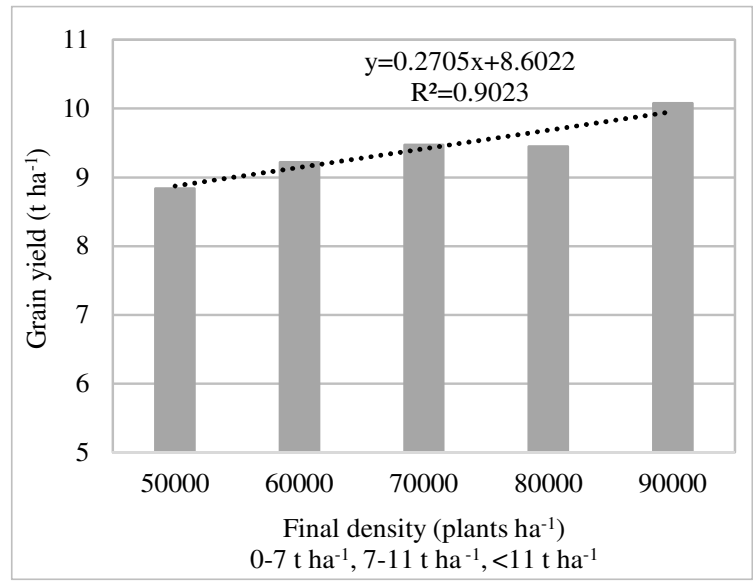

\section{The effect of plant density to yield components}

The tolerance of the increase of the plant density is a genetically determined characteristic of hybrids, is heavily influenced by the characteristics of the place of growing, very heavily by the growing year, the fore crop and other elements of the agrotechnics, the inputs. If we examine the output of the hybrids in the terms of their yields it becomes clear that the results are limited at the highest level by the season.

According to our results we can say that increasing the plant density effects negatively to all of the yield components. In our examinations from 2015 there was close negative correlation between the plant density and ear length $(\mathrm{r}=-0.83)$, and kernel number per rows $(\mathrm{r}=-0.81)$. The correlation is negative and loose between the plant density and ear thickness $(\mathrm{r}=-0.38)$, the ear diameter $(\mathrm{r}=-0.20)$, the cob diameter $(\mathrm{r}=-0.21)$ and thousand kernel weight [TKW] $(\mathrm{r}=-0.32)$. The number of the kernel rows is a constant characteristic, the plant density has no effect on it $(\mathrm{r}=-0.02)$. According to these results, we can say that the increasing of the plant density means decrease in the individual production at all of the breeds. The longer ears mean more kernels per rows, thus suggesting a higher individual production.

\section{CONCLUSIONS}

The results of many years of plant density experiments show that the hybrids that are commercially available are capable for production at a higher plant density level. At the same time, it has to be underlined that when determining the plant density optimum, not only the interaction of the type and plant density should be considered, but the capability of the cultivation area, the expected year effect and other main characteristics of the type as the level of plant density dependency, the characteristics of the ear, the agro technical and other defensive specifics. The development of the yield components at different phenological stages of the maize occurs during a long process. The heat and drought stress during this period of time significantly influences their development and their influence on the final yield. The different hybrids reach the technological maturation with different strategies, so despite the similar plant density curves, the plant density reactions are not uniform, but species-specific, that highlight the importance of further research and the importance of the individual evaluation.

\section{ACKNOWLEDGEMENTS}

The author thanks to the Breeding Team members at Research Site at Szatymaz, Hungary; to Professor Mihály Sárvári for the useful suggestions and effort. This work was supported by Dekalb-Monsanto Research Center in Hungary and Technology Development Department in Hungary and Romania. 


\section{REFERENCES}

Berzsenyi, Z.-Tokatlidis, I. S. (2012): Density dependence rather than maturity determines hybrid selection in dryland maize production. Agronomy Journal. 104. 2: 331-336.

Echarte, L.-Andrade, F. H.-Sadras, V. O.-Abbate, P. (2006): Kerne weight and its response to source manipulations during grain filling in Argentinean maize hybrids released in different decades. Field Crops Research. 96: 307-312.

Edmeades, G. O.-Daynard, T. B. (1979): The development of plant-to-plantvariablity in maize at different planting densities. Can. J. Plant Sci. 59: 561-576.

Edwards, J. W. (2016): Genotype X Environment interaction for plant density response in maize (Zea mays L.). Crop Science. 56: $1493-1505$

Li, J.-Xie, R. Z.-Wang, K. R.-Ming, B.-Guo, Y. Q.-Zhang, G. Q.Li, S. K. (2015): Variations in maize dry matter, harvest index, and grain yield with plant density. Agronomy Journal. 107. 3: 829-834.

Maddonni, G. A.-Otegui, M. E. (2004): Intra-specific competition in maize: early establishment of hierarchies among plants affects final kernel set. Field Crops Research. 85: 1-13.

Maddonni, G. A.-Otegui, M. E. (2006): Intra-specific competition in maize: Contribution of extreme plant hierarchies to grain yield, grain yield components and kernel composition. Field Crop Research. 97: 155-166

Molnár Zs.-Sárvári M. (2005): A vetésidő és a tőszám hatása a kukorica hibridek termésére. Agrártudományi Közlemények. 16 : 95-104.

Murányi E.-Pepó P. (2014): Különböző genotípusú kukorica hibridek tőszám sủríthetôségének vizsgálata csernozjom talajon. Ag rártudományi Közlemények. 56: 87-92.

Nagy, J. (2007): Maize production. Akadémiai Kiadó. Budapest.
Pepó P.-Murányi E. (2015): Tenyészterület vizsgálatok eltérő genotípusú kukorica (Zea mays L.) hibrideknél. Növénytermelés. 64 3. 59-75.

Ruzsányi L.-Csajbók J. (2001): Termésstabilitás és az évjárat kölcsönhatása a fontosabb szántóföldi növényeinknél. Agrártudományi Közlemények. 2: 41-46.

Sangoi, L. (2001): Understanding plant density effects on maize growth and development: an important issue to maximize grain yield. Ciencia Rural. 31: 159-168.

Sarlangue, T.-Andrade, F. H.-Calvino, P. A.-Purcell, L. C. (2007): Why do maize hybrids respond differently to variations in plant density? Agronomy Journal. 99: 984-991.

Sárvári, M.-Boros, B. (2010): The effect of plant density on the yield and yield safety of maize hybrids. 45 . hrvatski i 5 . Međunarodn simpozij agronoma. 15-19 veljače 2010. Opatija, Hrvatska. Zbornik Radova. Josip Juraj Strossmayer University Agriculture Faculty in Osijek.

Sárvári, M.-Boros, B. (2008): The effect of plant density on the yield and yield safety of maize hybrids in average and dry years. Cereal Res. Commun. 36: 1715-1718.

Sárvári, M.-El-Hallof, N.-Molnár, Zs. (2007): Effect of determining factors on maize yield with special regards to plant density. Cereal Res. Commun. 35. 2: 1037-1040.

Sárvári, M.-Boros, B. (2009): Response of maize hybrids to increasing plant density and its impact on yield. Analele Universitații din Oradea. Fascicula: Protecția Mediului. 14: 264-271.

Tollenaar, M. (1989): Genetic improvement in grain yield of commercial maize hybrids grown in Ontario from 1959 to 1988. Crop Sci. 29: 1365-1371.

Widdicombe, W. D.-Thelen, K. D. (2002): Row width and plant density effects on corn grain production in the Northern Corn Belt. Agronomy Journal. 94: 1020-1023. 
